\title{
Extrapancreatic insulin effect of glibenclamide
}

\author{
H.Mulder ${ }^{1}$, W.Schopman Sr. ${ }^{2}$, and A.J. van der Lely ${ }^{3}$ \\ ${ }^{1}$ Department of Internal Medicine, Eudokia Hospital, ${ }^{2}$ Department of Endocrinological Biochemistry, Municipal Hospital and \\ ${ }^{3}$ Department of Internal Medicine, University Hospital Dijkzigt, Rotterdam, Netherlands
}

Received: May 15, 1990/Accepted in revised form: October 4, 1990

Summary. In eight patients with uncomplicated non insulin dependent diabetes mellitus, serum insulin levels, serum C-peptide levels and blood glucose levels were measured before and after oral administration of glibenclamide $0.1 \mathrm{mg} / \mathrm{kg}$ body weight and a test meal, or after a test meal alone.

The rise in serum insulin levels persisted longer after glibenclamide. The initial rise in serum insulin was of the same magnitude in both situations, as was the rise in serum C-peptide levels during the entire $5 \mathrm{~h}$ study.

It is concluded that glibenclamide is able to maintain a more protonged increase in serum insulin levels by inhibiting the degradation of insulin in the vascular endothelial cells of the liver. The inhibition contributes to the blood glucose lowering effect of glibenclamide.

Key words: Insulin, glibenclamide; C-peptide, insulin catabolism, diabetes

Sulphonylureas were serendipitously discovered to have a glucose-lowering effect in the course of clinical studies on the treatment of typhoid fever [1]. It soon became clear that they had both a blood glucose level lowering effect as well as an insulin-releasing effect [2]. Sulphonylureas increase the number of the insulin receptors [3]. Another mechanism which might explain the extrapancreatic effect of sulphonylureas in lowering blood glucose, has only relative recently been discovered. Insulin is secreted by the pancreas into the portal vein and it must pass the liver and the endothelial surface of its vascular bed before reaching the systemic circulation. Decreasing insulin breakdown by the endothelial cells could result in an 'insulin-saving' effect. The potential 'insulinsaving' effect of the sulphonylurea glibenclamide has been studied by comparing insulin $\mathrm{C}$ peptide and blood glucose levels before and after B-cell stimulation by a meal alone, or a combined meal and glibenclamide, in 8 patients with mild non-insulin dependant diabetes mellitus.

\section{Patients and methods}

There eight patients suffering from uncomplicated non insulin dependant diabetes mellitus in the study (mean age 56 (6) $\mathrm{y} ; 6 \mathrm{~m}$ and $2 \mathrm{f}$; height $169(5 \mathrm{~cm})$; weight $71(5) \mathrm{kg}$. The mean duration of the in diabetes was 5 (1) y. None of the patients was taking any medicine. They all had normal renal and hepatic function, none was suffering from malabsorption, and none had any other endocrine disorder.

Glibenclamide test: Before and 30,60, 90,120,180 and $360 \mathrm{~min}$ after oral glibenclamide $0.1 \mathrm{mg} \cdot \mathrm{kg}^{-1}$ body weight blood samples were taken for measurement of serum insulin and C-peptide levels and blood glucose. The patients ate a standardized meal [12] directly after taking the dose of glibenclamide; it consisted of two $50 \mathrm{~g}$ boiled eggs, $60 \mathrm{~g}$ white, untoasted, sliced bread covered with $12 \mathrm{~g}$ butter, and $200 \mathrm{ml}$ fresh, squeezed orange juice supplemented with $10 \mathrm{~g}$ sugar (beet saccharose). It contained $18 \mathrm{~g}$ proteins, $22 \mathrm{~g}$ lipids and $60 \mathrm{~g}$ carbohydrates and presented about $500 \mathrm{kcal}$. After about one week each patient underwent a second test in which the same standardized meal was eaten but without the dose of glibenclamide. In the first four patients the glibenclamide test was performed first. The patients sat comfortably in an armchair during the test.

Insulin assay: Serum insulin levels were measured by radioimmunoassay using a guinea pig antiporcine insulin antibody and charcoal dextran separation of bound - and free ${ }^{125}$ I-labelled insulin. The prepar insulin standard was the First International Reference Preparation.

C-peptide assay Serum C-peptide levels were measured with a Novo C-peptide kit (Novo Institute Denmark). Statistical analysis. Results are expressed as mean with (SEM). Statistical significance was analysed by Student's t-test for paired data.

\section{Results}

The serum insulin and serum C-peptide levels and blood glucose before and after a standardized meal alone and after a standardized meal + glibenclamide are shown in Fig. 1. Basal values of blood glucose, insulin and C-peptide before either a standardized meal alone or a standardized meal + glibenclamide were not significantly different.

The standardized meal alone was followed by a rapid, marked increase in blood glucose levels, reaching a maximum of $16.8(1.3) \mathrm{mmol} \cdot \mathrm{1}^{-1}$ at $90 \mathrm{~min}$, and associated with a delayed and blunted response in plasma insulin - maximum of $\left.18.1(0.8) \mu \mathrm{U} \cdot \mathrm{ml}^{-1}\right)$ at $120 \mathrm{~min}$. Blood glucose 

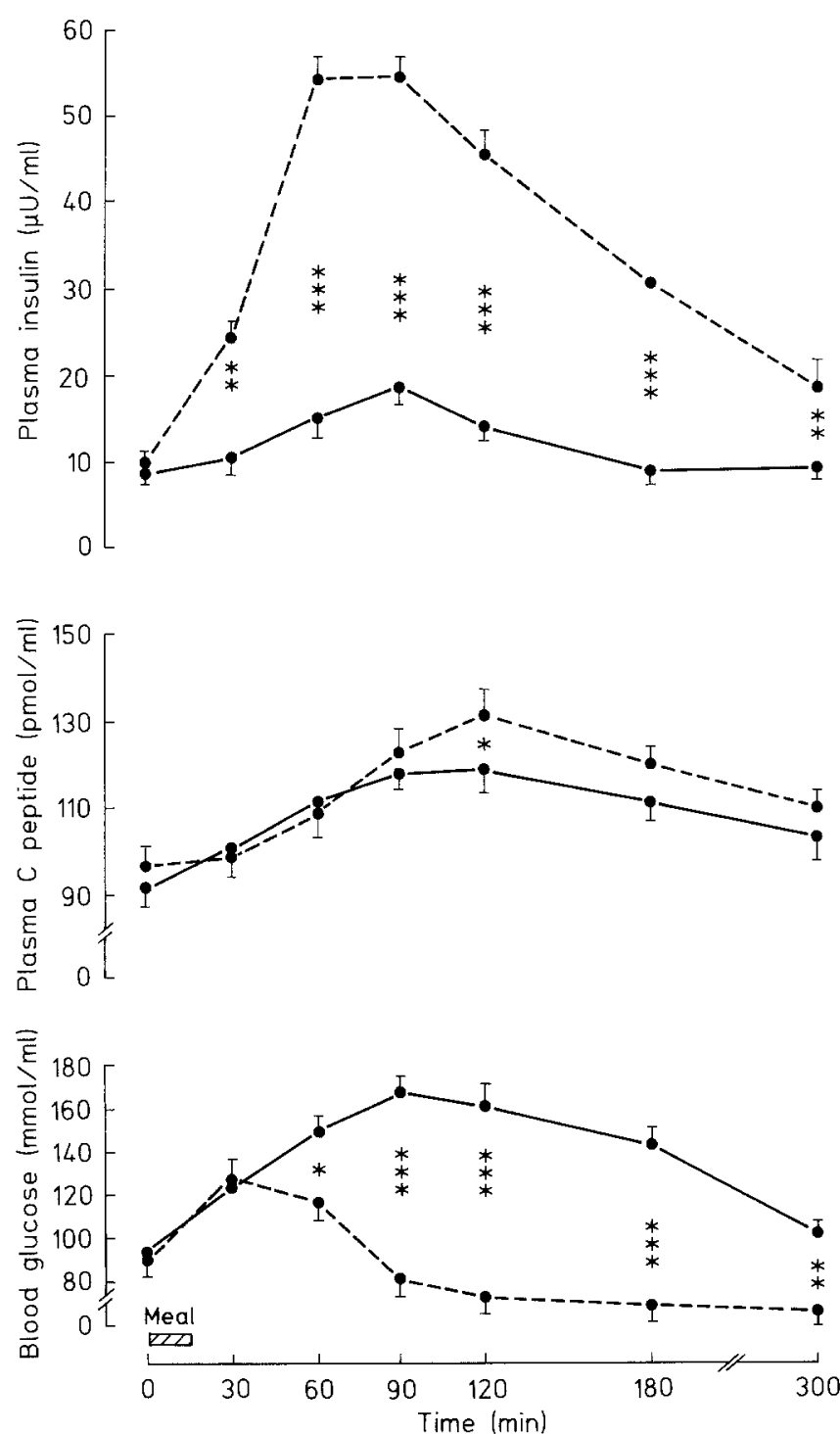

Fig. 1. Mean serum insulin, C-peptide and blood glucose levels in eight patients with from non-insulin dependent diabetes mellitus, after a test meal alone [- ${ }^{-}$, and a test meal with glibenclamide $0.1 \mathrm{mg} / \mathrm{kg}$ body weight [---]. Error bars indicate SEM

$*=P<0.05 \quad * *=P<0.01 \quad * * *=P<0.001$

had returned to its basal value at the end of the test, whereas serum insulin and serum C-peptide levels were still elevated at that time.

After a standardized meal + glibenclamide the rise in blood glucose was markedly truncated: maximum of 12.9 (1.1) $\mathrm{mmol} \cdot 1^{-1}$ at $30 \mathrm{~min}$. After $30 \mathrm{~min}$, the blood glucose level rapidly decreased to a minimum at $300 \mathrm{~min}$ of 8.1 (1.0) $\mathrm{mmol} \cdot \mathrm{l}^{-1}$. The rise in serum insulin levels was steeper and reached a level three-times higher than after the standardized meal alone: maximum at $60 \mathrm{~min}$ to $90 \mathrm{~min}$, with a steady state level of $56 \mathrm{U} \cdot \mathrm{ml}^{-1}$.

In contrast, the increase in serum C-peptide levels measured after the standardized meal + glibenclamide was almost identical to that after the me al alone; the sole exception was at $120 \mathrm{~min}-1.3(1.0) \mathrm{pmol} \cdot 1^{-1}$.

The AUC (0-300 min) were calculated for the three blood levels. After a standardized meal + glibenclamide there was a significantly by smaller increase in blood glucose than after the standardized meal alone: 2450 (158) versus $3620(159) \mathrm{mmol} \cdot 1^{-1}(P<0.001)$. The increase in serum insulin levels after the standardized meal + glibenclamide was significantly greater $(13020$ (2420) versus $\left.5200(1410) \mu \mathrm{U} \cdot \min \cdot \mathrm{ml}^{-1} ; \quad P<0.001\right)$. Although at 120 min serum C-peptide levels after a standardized meal + glibenclamide were significantly higher than after the meal alone, the change in serum C-peptide level (as the AUC) was not significantly different in the two situations (419 (48) versus $\left.381(45) \mathrm{pmol} \cdot \mathrm{min} \cdot \mathrm{ml}^{-1}\right)$.

\section{Discussion}

The liver plays a central role in the catabolism of insulin, removing approximately $50-70 \%$ of the hormone secreted by the pancreas from the portal vein before it reaches the systemic circulation [4]. The 'insulin-saving' effect of glibenclamide in 8 patients with non insulin dependent diabetes was examined here. The 'insulin-saving' effect was taken to mean inhibition of the breakdown of insulin by the endothelial cells of the liver. The B-cell mass of the pancreas was stimulated by use of glibenclamide as a secretagogue. Proinsulin is the product of biosynthesis in the B-cells [5]. Proinsulin, excreted by B-cells, is split into insulin and C-peptide in equimolar concentrations [6]. Therefore the C-peptide concentration is also an indicator of B-cell function. The vast majority of C-peptide is catabolized by the kidney [7] and not by the liver. Hepatic extraction of C-peptide is about $50 \%$ lower than that of insulin [8]. It has been shown that vascular endothelial cells of the liver actively bind and degrade insulin [9]. The insulin - C-peptide ratio is dependent upon the interaction of many factors related to the secretion, metabolism, distribution and half-life (insulin $4 \mathrm{~min}$ and proinsulin $30 \mathrm{~min} ;[10])$ of insulin and proinsulin. In the study two secretagogues for insulin secretion were employed. Patients received a standardized meal alone as a secretagogue, or a standardized meal together with glibenclamide. Both tests provoked an equal increase in serum C-peptide levels. In both tests in the first $30 \mathrm{~min}$, there was an equal rise in serum insulin level, but from then on wards serum insulin levels still rose in patients also given glibenclamide. When the patients did not take glibenclamide, serum insulin levels fell after $30 \mathrm{~min}$.

Although the rise in serum C-peptide levels after a standardized meal + glibenclamide appears higher than after a standardized meal alone, no significant difference was found when measuring the AUCs. Considering the difference found in serum insulin levels in the two tests, and the fact that B-cells secrete C-peptide and insulin in equimolar concentrations, it appears that glibenclamide can raise insulin levels not only by augmentation of secretion, but also by a selective decrease in the catabolism of insulin in the liver. Inhibition of the degradation of insulin in the liver could be the explanation for the slower fall in insulin levels in diabetic patients on glibenclamide. A similar conclusion was drawn by Almer et al. [11] and Sheen et al. [12], using glipizide as the sulphonylurea derivative, and by Marshall et al. [13], using other sulphonylureas. 
It is suggested that the most important mechanism for the catabolism of insulin is receptor-linked degradation. After a therapeutic dose it is possible that the antidiabetogenic effect of glibenclamide is also achieved by inhibition of the receptor-linked insulin degradation system of the endothelial cells of the liver. In doing so glibenclamide would be inhibiting the catabolism of insulin in the liver. Such an action would have a profound effect upon the overal handling of insulin by the body.

\section{References}

1. Jambon S, Chaptal J, Vedel A, Schaap J (1942) Accidents hypoglycemiques graves par un sulfamido-thiadiazol. Montpell Med 21: $441-445$

2. Rafaelson OF (1959) Action of oral antidiabetic drugs on carbohydrate metabolism of isolated rat diafragm. Metabolism 8: 195-201

3. Feinglos MV, Leboritz HA (1978) Sulfonylureas increase the number of insulin receptors. Nature (London) 276:184-187

4. Field JB (1973) Extraction of insulin by liver. Ann Rev Med 24: 309

5. Steiner DF, Kemmler W, Clark JL, Oyer PE, Rubenstein AH (1971) The biosynthesis of insulin. Handbook of Physiology, Section 7, Vol 1. American Physiological Society, Washington DC, pp 36-40
6. Rubenstein AM, Clark JL, Melani F, Steiner DF (1969) Secretion of proinsulin C-peptide by pancreatic B-cell and its circulation in blood. Nature 224: 697-699

7. Katz AL and Rubenstein AH (1973) Metabolism of proinsulin, insulin and C-peptide in the rat. J Clin Invest 52: 1113-1121

8. Kühl C, Faber OK, Homnes P, Lindkaer-Jansen S (1978) C-peptine metabolism and liver. Diabetes 27 [Suppl 1]: 197-200

9. Kaiser N, Vlodovsky I, Tur-Sinai A, Cerasi E (1982) Binding, internalization and degradation of insulin in vascular endothelial cells. Diabetes 31: 1077-1084

10. Sonksen PH, Tompkins CV, Srivastava MC, Nabarro JDN (1973) A comparative study on the metabolism of human insulin and porcine proinsulin in man. Clin Sci Mol Med 45: 103

11. Almer LO, Johansson E, Melander A, Wählin-Boll (1982) Influence of sulfonylureas on the secretion, disposal and effect of insulin. Eur J Clin Pharmacol 22: 27-32

12. Scheen AJ, Lefebvre PJ, Lugckx AJ (1984) Glipizide increases plasma insulin but not C-peptide level after a standardized breakfast in type 2 diabetic patients. Eur J Clin Pharmacol 26: 471-474

13. Marshall A, Gingerich RL, Wright PH (1970) Hepatic effect of sulfonylureas. Metabolism 19: 1046-1052

H. Mulder MD

Department of Internal Medicine

Ysselland Ziekenhuis

Bergselaan 62

NL-3037 CB Rotterdam

The Netherlands 